\title{
Making ends meet in South Africa
}

As it struggles to overcome the legacy of apartheid, South Africa needs to protect and strengthen the most productive parts of its science base. That requires a tough approach to the redistribution of resources - and determination to tackle big spenders.

WITH the immediate euphoria of the ending of apartheid receding rapidly, South Africa is struggling with the daunting task of forging a modern industrial economy able both to meet the needs of all its people, and ensure economic success in the global market-place. A critical component of these is the restructuring of its science base to ensure that both goals are pursued as effectively as possible. In doing so, South Africa needs to redress the idiosyncrasies of its past allocation of research funding. These were based on the priorities of a besieged nation, pre-occupied with maintaining apartheid and the privileges it conferred on its white minority. Reform in this sphere, as in so many others, is long overdue.

Significant progress is represented, at least in principle, by the white paper that was published in September, and which will soon come into effect (see page 11). The paper sets out some useful proposals for reorganizing the way that research funds are distributed between different sectors, and linking research to economic and social needs. Disappointingly, it fails to provide incentives to the private sector to invest more in research.

One reason being given for not offering tax concessions, either for increased $R \& D$ spending or for donations to museums by either companies or individuals, is that the revenue services lack the capacity to administer them. But that is a weak excuse, given the potential benefits at stake and the relatively low cost of employing a few skilled accountants.

There is also much sound sense in the recent report of the National Commission on Higher Education, which sets out a framework for the future financing of tertiary education. The government's response is due early next year. In addition to accepting radical proposals on student funding, it needs to spell out clearly how the research component of university funding is to be financed. At present, fifteen per cent of federal support for universities is allocated for research using a formula based on publications in accredited journals. But one result is that this strongly favours the five major universities, in which almost two-thirds of South Africa's research is carried out. The government should maintain these existing centres of productivity. But, in return, it should demand that they continue steadily to transform themselves into institutions that are broadly representative of South African society - or at least the region which they serve.

Another critical issue is how limited research funds should be distributed more effectively among the seven research councils (which carry out significant proportions of their research inhouse), the proposed National Research Foundation (which will distribute funds to the universities, polytechnics and museums), and the new National Innovation Fund. Closing down or privatizing large sections of some of the research councils may be essential if they are unproductive, or perform consultancy work which does not merit public subsidy by the taxpayer. And it would be a mistake if both the military research budget and that of the Atomic Energy Corporation - the two greatest dinosaurs of the apartheid era in terms of research spending were to escape the knife.

Dismantling outdated structures can be as difficult as creating new ones. The new minister, Lionel Mtshali, has the oppor- tunity to make his mark, but will need political backing to do so. If the government has the courage to implement the requisite changes, 1998 could turn out to be the year of reckoning and of exciting opportunity for South African science.

\section{Peer review and the courts}

Despite an out-of-court settlement last week, science must not rely on litigation to keep its house in order.

A TWELVE-YEAR battle between Immunex and Cistron has ended with the payment by the former to the latter of $\$ 21$ million, as well as patent rights to the interleukin-1 protein at the centre of their dispute (see page 4). Cistron sued Immunex because it believed that a scientist at that company had misappropriated information about the protein's structure from a paper, submitted to Nature by a Cistron-sponsored team, which he was asked to review. Cistron pointed to suspicious similarities: subsequent patent applications filed by Immunex replicated errors in DNA sequences contained in the original.

If the case had come to court, it would have called for a potentially significant ruling on the untested question of whether the confidentiality of the peer review process is legally binding, and on the extent to which a reviewer is legally (as well as ethically) constrained in his or her use of that material. This notion of confidentiality underpins the entire peer review system. Whether the law of the United States underpins that notion is a question which for now must, after all, remain unanswered.

Cistron would have argued that the confidential nature of the reviewing task is not only essential in the conduct of science, but also well understood by the scientific community, through custom and practice. Immunex's lawyers would have said that, in practice, the precise requirements of confidentiality are poorly understood - and indeed are only pursued at the reviewer's discretion.

The decision by Immunex to pay $\$ 21$ million to Cistron, rather than take its argument to court, is welcome. Though considerably less than Cistron asked for, it is a useful amount of compensation for the loss of information on a protein which has turned out to be of very little commercial value. It will ensure an early and happy retirement for each of Cistron's seven employees, should they suddenly tire of molecular biology. More importantly, it will send a clear signal to any scientist who may be torn between corporate zeal and professional ethics that the former practised at the expense of the latter can have a high price.

But satisfactory as it may be, the outcome of a high-visibility case like this one can have only a marginal effect in holding the line against scientific misconduct. More often than not, there are no faulty data with which to trace misbehaviour, and it is only the decency and honesty of individual researchers that hold the line, and maintain the integrity of science. In particular, much too often, researchers insist on tight confidentiality when they are authors, but are markedly less rigorous when they are sent papers to review. They too need to take note of the dangers. 